\title{
Effect of waste water of the pharmaceutical industries, sugar and flour mill on growth and yield of Pisum sativum $\mathbf{L}$.
}

Raees Khan ${ }^{1}$, Muhammad Nawaz ${ }^{1}$, Zulqarnain ${ }^{1}$, Saiful Islam ${ }^{1}$, Hazrat Ali $^{1}$, Sartaj Aziz ${ }^{1}$, Fazal Wahid ${ }^{2}$, Saeed ur Rehman ${ }^{2}$ and Muhammad Rahim $^{3 *}$

1. Department of Botany, Government College Peshawar, Khyber Pakhtunkhwa-Pakistan

2. Department of Chemistry, Government College Peshawar, Khyber Pakhtunkhwa-Pakistan

3. School of Chemical Sciences, Universiti Sains Malaysia, 11800 Pulau Penang-Malaysia

*Corresponding author's email:kpk566@gmail.com

Citation

Raees Khan, Muhammad Nawaz, Zulqarnain, Saiful Islam, Hazrat Ali, Sartaj Aziz, Fazal Wahid, Saeed ur Rehman and Muhammad Rahim. Effect of waste water of the pharmaceutical industries, sugar and flour mill on growth and yield of Pisum sativum L. Pure and Applied Biology. Vol. 8, Issue 4, pp2153-2158. http://dx.doi.org/10.19045/bspab.2019.80160

Received: 13/05/2019 Revised: $15 / 07 / 2019$ Accepted: 19/07/2019 Online First: 27/07/2019

\section{Abstract}

Industries are the main source of surface and ground water pollution. Whereas, water pollution is a major cause of health hazard to human beings, animals and plants. As such, industrial effluents badly affect growth and development of food crops. In the present study, effect of the wastewater of pharmaceutical industries, sugar and flour mills was evaluated on the growth and yield of pea plant (Pisum sativum L.). Tap water was used as controlled. The field experiments were carried out during the growing season of February, 2017. The results of field experiments showed that there is no significant difference between plant germination, growth, development, plant height, number of branches per plant and seed weight (fresh and dry). Similarly, in lab experiments, no considerable difference was observed between controlled (Tap water) and wastewater treatments. We argue that small scale effluents have no effect on the growth and yield of the pea plants. It has been observed that less than $10 \%$ of the wastewater is treated and the rest of untreated wastewater is discharged into the nearby water bodies throughout Pakistan. Therefore, proper treatment system for industrial effluents is recommended to meet the international standards.

Keywords: Germination; growth; Pisum sativum; yield

\section{Introduction}

Industrial effluents are the major source of surface and ground water contamination. These contaminations may cause numerous diseases [1], among them, shorter life expectancy is the major adverse effect of the industrial effluents [2]. The use of industrial effluents for irrigation has emerged in the recent past because it contains sufficient quantities of NPK (nitrogen, phosphorous and potassium) along with calcium which are important nutrients for development and 
growth of plants [3]. As such, industrial effluents contain toxic organic and inorganic compounds [4-6]. Therefore, it is very necessary to study the effect of industrial wastewater on crops [7].

Industrial wastewater has been used for irrigation of food crops, pea plant (Pisum sativum L.) particularly. Pisum sativum is consumed in variety of ways throughout the globe and their demand is increasing day by day $[8,9]$. The increasing need of protein rich raw materials for animal feed and human nutrition have led to greater interest in pea as a protein source [10]. Green peas are good source of natural proteins and carbohydrates [11-13]. Pisum sativum is an annual plant, with a life cycle of one year. It is a cool season-crop grown in many parts of the world. It can be grow in the temperature range of 13 to $18{ }^{\circ} \mathrm{C}$.

The present study was designed to investigate the effect of untreated wastewater of pharmaceutical industries, sugar and flour mills on the growth and development of pea plants (Pisum sativum L.).

\section{Materials and methods}

Seeds of Pisum sativum L. were collected from herbarium of Nuclear Institute of Food and Agriculture (NIFA) Tarnab, Peshawar, Khyber Pakhtunkhwa, Pakistan.

Wastewater was sampled from three points (i). Pharmaceutical industrial zone, Hayatabad, Peshawar (ii). Naguman Flour Mill, Peshawar, (iii). Khazana Sugar Mill, Peshawar, Khyber Pakhtunkhwa. The wastewater was collected in clean plastic bottles of $10 \mathrm{~L}$ on daily basis. The collected wastewater was used on the same day of collection.

The soil was sampled from agricultural land near Peshawar, Khyber Pakhtunkhwa, dried and homogenized by passing through sieve. The soil was stored in clean plastic bags.

\section{Field experiments}

The seeds were grown in pots. Soil of 28.50 $\mathrm{kg}$ was filled in each pot and five seeds of
Pisum sativum were sown in one pot. Four replicates were made for each pot. $500 \mathrm{~mL}$ of wastewater was given to each pot daily. Whereas, tap water was used as control.

\section{Laboratory experiments}

Lab experiments were conducted using Petri dishes. Two filter papers were placed in a Petri dish and seed of the Pisum sativum was added at room temperature. One milliliter wastewater was added to the nominated Petri dishes on daily basis at around 3:00 pm to 4:00 pm. As such, $1 \mathrm{~mL}$ tap water was added to the Petri dishes under controlled experiment every day. The changes were observed on daily basis.

\section{Results and discussion \\ Field experiment}

The results of growth rates, heights and seeds are shown in (Table 1). Initial growth and development of plants showed no significant difference. The average final heights of plants were observed 20.22 \pm 0.27 , $22.09 \pm 0.08,20.13 \pm 0.66$ and $27.05 \pm 0.04 \mathrm{~cm}$ for tap water, Khazana Sugar Mill, Naguman Flour Mill and pharmaceutical industrial wastewater treated plants, respectively. In addition, the average number of branches was observed $\quad 10.07 \pm 0.54, \quad 10.12 \pm 0.82$, $11.09 \pm 0.99$ and $13.14 \pm 0.06$ for tap water, Khazana Sugar Mill, Naguman Flour Mill and pharmaceutical industrial wastewater treated plants, respectively. As such, the average weight of fresh seed was found $1.21 \pm 0.05, \quad 0.80 \pm 0.04, \quad 1.12 \pm 0.00$ and $1.09 \pm 0.02$ grams for tap water, Khazana Sugar Mill, Naguman Flour Mill and pharmaceutical industrial wastewater treated plants, respectively. Whereas, the average dry weight of seeds was found 0.90 gram for the plants treated with tap water, wastewater of pharmaceutical industries and Naguman Flour Mill, respectively, while the average weight of dry seed for plants treated with wastewater of Khazana Sugar Mill was observed 0.60 gram. First flowers were observed in the plants treated with 
wastewater of Khazana Sugar Mill and pharmaceutical industries, respectively.

Taller plants were observed in the pots treated with wastewater of pharmaceutical industries (on average $27 \mathrm{~cm}$ ). While shortest plants were observed in the pots treated with tap water (on average 20). Similarly, large number of branches were observed in pots treated with pharmaceutical industrial effluents (on average 13), followed by Naguman Flour Mill (on average 11), Khazana Sugar Mill (on average 10) and tap water (on average 10). The seeds per pod were greater in Naguman Flour Mill wastewater treated plants (on average 4) as compare to controlled (tap water treated), Khazana Sugar Mill and pharmaceutical industrial wastewater treated plants. Interestingly, fresh weight of the seeds obtained from plants treated with tap water was heavier than all (on average 1.2 grams). As such, dry weight was found 0.90 grams for tap water, pharmaceutical industries and Naguman Flour Mill wastewater treated plants, although lighter weight was observed for the plants treated with Khazana Sugaar Mill wastewater. The average percentage of germination was observed $93.75 \%$ for tap water treated plants. The second higher percentage was found for Naguman Flour Mill wastewater treated plants (on average $90.62 \%)$, followed by Khazana Sugar Mill $(72.00 \%)$ and pharmaceutical industries $(62.50 \%)$ wastewater treated plants. In addition, first flowers were observed in Khazana Sugar Mill and pharmaceutical industrial wastewater treated plants while tap water and Naguman Flour Mill wastewater treated plants showed later appearance of flowers.

Two-way ANOVA Analysis was used for the treatments to compare them with the controlled parameter. The two-way ANOVA compares the mean differences between groups that have been split in two independent variables (called factors). The primary purpose of two-way ANOVA is to understand if there is an interaction between the two independent variables on the dependent variable.

Results of statistical analysis are shown in (Table 2). The results of statistical analysis revealed that there was no effect of Naguman Flour Mill and pharmaceutical industries wastewater treated plants on the flower appearance, plant height, number of branches, number of seeds per pod and weight of seeds. However we observed significant relation of Khazana Sugar Mill wastewater treated plants with the observed variables. The significant results of Khazana Sugar Mill wastewater treated pots showed positive relation with flower appearance, plant height, number of branches, number of seeds per pod and weight of seed. Mahvi et al. [14] showed that the using of wastewater for irrigation increases the growth parameters with the exception of aerial parts than the control. Khouri et al. [15] observed increased yield(from 28 to $51 \%$ ) in wheat, rice, beans, cotton and potatoes compared with fresh water irrigation along with the application of commercial fertilizers. Khazana Sugar Mills wastewater may contain organic nutrients of the sugarcane, which might responsible for the positive relation of the treatment with the growth parameters. Effluents often contain significant quantity of organic and inorganic nutrients, such as NPK along with many toxic wastes, microorganisms [16] and induces increased antioxidant enzyme activities in plants. High concentration of nutrients in effluents contributes to high crop yields [12].

\section{Lab experiment}

The results of laboratory experiments are shown in (Table 3). The laboratory experiments were conducted to observe the initial germination of seeds treated with waste water of pharmaceutical industries, Naguman Flour Mill, Khazana Sugar Mill and tap water. 
Table 1. Average data of different parameters of the field experiments

\begin{tabular}{|c|c|c|c|c|c|c|c|}
\hline & $\begin{array}{c}\text { Germination } \\
\text { Percentage }\end{array}$ & $\begin{array}{c}\text { Plant Height } \\
\mathbf{( c m )}\end{array}$ & $\begin{array}{c}\text { Number of } \\
\text { Seeds/Pod }\end{array}$ & $\begin{array}{c}\text { Number of } \\
\text { Branches/Plant }\end{array}$ & $\begin{array}{c}\text { Fresh Weight } \\
\text { of Seed (g) }\end{array}$ & $\begin{array}{c}\text { Dry Weight } \\
\text { of Seed (g) }\end{array}$ & $\begin{array}{c}\text { Flower } \\
\text { Appearance }\end{array}$ \\
\hline Tap Water & $93.75 \pm 0.34$ & $20.22 \pm 0.27$ & $3.46 \pm 0.91$ & $10.07 \pm 0.54$ & $1.21 \pm 0.05$ & $0.91 \pm 0.11$ & \\
\hline Sugar Mill & $72.00 \pm 1.04$ & $22.09 \pm 0.08$ & $3.44 \pm 0.87$ & $10.12 \pm 0.82$ & $0.80 \pm 0.04$ & $0.60 \pm 0.07$ & $1 \mathrm{st}$ \\
\hline Flour Mill & $90.62 \pm 0.76$ & $20.13 \pm 0.66$ & $4.41 \pm 0.54$ & $11.09 \pm 0.99$ & $1.12 \pm 0.00$ & $0.92 \pm 0.04$ & \\
\hline $\begin{array}{c}\text { Pharmaceutical } \\
\text { Industries }\end{array}$ & $62.50 \pm 0.95$ & $27.05 \pm 0.04$ & $3.40 \pm 0.92$ & $13.14 \pm 0.06$ & $1.09 \pm 0.02$ & $0.93 \pm 0.06$ & $1 \mathrm{st}$ \\
\hline
\end{tabular}

Table 2. Two-way ANOVA results of field experiments

\begin{tabular}{|c|c|c|c|c|}
\hline & Df & Sum sq & Mean sq & F value \\
\hline Sugar Mill & 1 & 304.06 & 304.06 & 2120.86 \\
\hline Flour Mill & 1 & 1.44 & 1.44 & 10.036 \\
\hline Pharmaceutical Industrial & 1 & 0.13 & 0.13 & 0.897 \\
\hline Residuals & 2 & 0.29 & 0.14 & 0.08 \\
\hline
\end{tabular}

Table 3. Average data of different parameters of lab experiments

\begin{tabular}{|c|c|c|c|c|}
\hline & Plumule growth $(\mathrm{cm})$ & Radicle growth (cm) & Germination Initiation & Cotyledon Observed \\
\hline Tap Water & $3.11 \pm 0.08$ & $7.23 \pm 0.06$ & $66.43 \%$ & $50.03 \%$ \\
\hline Khazana Sugar Mill & $1.11 \pm 0.04$ & $9.08 \pm 0.07$ & $58.30 \%$ & $83.09 \%$ \\
\hline Naguman Flour Mill & $2.04 \pm 0.07$ & $10.15 \pm 0.10$ & $41.60 \%$ & $83.44 \%$ \\
\hline Pharmaceutical Industries & $1.09 \pm 0.11$ & $8.13 \pm 0.08$ & $25.04 \%$ & $16.05 \%$ \\
\hline
\end{tabular}


The appearance of cotyledons was slow in tap water treated plants while the appearance of cotyledons was very high in wastewater of Naguman Flour Mill and Khazana Sugar Mill treated plants.

Germination termination was slower in pharmaceutical industrial wastewater treated plants. The overall germination rate was high in tap water as compare to industrial wastewater. Industrial wastewater of pharmaceutical industries has the lowest germination percentage among all the treatments. Long plumule was observed in tap water whereas, the shortest was observed for Khazana Sugar Mill and pharmaceutical industries wastewater treated plants. However, long radicle was observed in wastewater of Naguman Flour Mill treated plants as compare to tap water and other treatments.

The results of statistical analysis of two-wayANOVA are shown (Table 4). The statistical analysis revealed that there was no significance difference between controlled (tap water treated) and un-controlled (wastewater treated) treatments. The twoway-ANOVA analysis showed that wastewater treatments have no relation with the germination percentage, germination initiation, germination termination, plumule and radicle length. Kaushik \& Garg [17] carried out a research on germination, detention index, physiological growth parameters and plant stains of two cultivars of Surghum. The textile wastes did not illustrate any restrict effect on seed growth at low concentration. Zille et al. [18] confirmed that the household and industrial polluted water affected the germination and growth of seeds and seedlings of different species slightly.

Table 4. Two-way ANOVA result of lab experiments

\begin{tabular}{|c|c|c|c|c|c|}
\hline & Df & Sum sq & Mean sq & F value & P value \\
\hline $\begin{array}{c}\text { Pharmaceutical } \\
\text { Industries }\end{array}$ & 1 & 1386 & 1386 & 40.469 & 0.9 \\
\hline Sugar Mill & 1 & 4479 & 4479 & 130.78 & $\mathbf{0 . 0 5}$ \\
\hline Flour Mill & 1 & 146 & 146 & 4.264 & 0.2 \\
\hline Residuals & 1 & 34 & 34 & --- & --- \\
\hline
\end{tabular}

\section{Conclusion}

The effect of untreated industrial wastewater was studied on the growth and development of Pisum sativum L. Initial growth and development of plants showed no significant difference. The average final heights of plants were observed 20.22 \pm 0.27 , $22.09 \pm 0.08,20.13 \pm 0.66$ and $27.05 \pm 0.04 \mathrm{~cm}$ for tap water, Khazana Sugar Mill, Naguman Flour Mill and pharmaceutical industrial wastewater treated plants, respectively. In addition, the average number of branches was observed $\quad 10.07 \pm 0.54, \quad 10.12 \pm 0.82$, $11.09 \pm 0.99$ and $13.14 \pm 0.06$ for tap water, Khazana Sugar Mill, Naguman Flour Mill and pharmaceutical industrial wastewater treated plants, respectively. The average dry weight of seeds was found 0.90 gram for the plants treated with tap water, wastewater of pharmaceutical industries and Naguman Flour Mill, while the average weight of dry seed for plants treated with wastewater of Khazana Sugar Mill was observed 0.60 gram. Interestingly, fresh weight of the seeds obtained from plants treated with tap water was heavier than all (on average 1.2 grams). The laboratory experiments were conducted to observe the initial germination of seeds. The appearance of cotyledons was slow in tap water treated plants while the appearance of cotyledons was very high in wastewater of Naguman Flour Mill and Khazana Sugar Mill treated plants. Germination termination was slower in pharmaceutical industrial wastewater treated plants. The overall germination rate was high in tap water as 
compare to industrial wastewater. Long plumule was observed in tap water whereas, the shortest in Khazana Sugar Mill and pharmaceutical industries wastewater treated plants. However, long radicle was observed in wastewater of Naguman Flour Mill treated plants as compare to tap water and other treatments.

\section{Authors' contributions}

Conceived and designed the experiments: Zulqarnain, F Wahid \& M Rahim, Performed the experiments: $R$ Khan \& $M$ Nawaz, Analyzed the data: M Rahim, S Islam, H Ali, S Aziz \& SU Rehman, Contributed reagents/ materials/ analysis tools: Zulqarnain \& Fazal Wahid, Wrote the paper: M Rahim.

\section{References}

1. WHO (2002). Water Pollutants: Biological Agents, Dissolved Chemicals, NonDissolved Chemicals, Sediments, Heat, World Health Organization.

2. WHO (2003). The World Health Report, Shaping the Future, World Health Organization, 1211, Geneva 27, Switzerland.

3. Niroula B (2003). Comparative effects of industrial effluents and sub-metropolitan sewage of biratnagar on germination and seedling growth of rice and blackgram. Our Nature 1: 10-14.

4. Raman S, Biswas AK, Kundu S, Saha JK \& Yadav RBR (2002). Effect of distillery effluent on seed germination in some vegetable crops. Bioresour Technol 82: 273 275.

5. Rahim M, Imdad U, Khan A \& Mas Haris MRH (2016). Health risk from heavy metals via consumption of food crops in the vicinity of District Shangla. J Chem Socie Pak 38(1): 177-185.

6. Rahim M, Ullah I, Khan A, Mas Haris MRH \& Ahmad N (2014). Spatial distribution and risk assessment of heavy metals from drinking water in district Shangla. Science International (Lahore) 26(4): 1625-1630.
7. Thamizhiniyan P, Sivakumar PV, Lenin M \& Sivaraman M (2009). Sugar mill effluent toxicity in crop plants. J Phytol 1: 68-74.

8. Khan A, Ibrahim M, Ahmad N\& Anwar SA (1994). Accumulation of heavy metals in soils receiving sewage effluents. J Agric Res 32: 525-533.

9. Kamil MA \& Singh BR (2015). The effect of fertilizer additions on the solubility and plant-availability of $\mathrm{Cd}, \mathrm{Ni}$ and $\mathrm{Zn}$ in soil. Nutr Cycl Agroecosys 62: 287-296.

10. Sandalio LM, Dalurzo HC, Gomez M, Romero-Puertas MC \& Del-Rio LA (2001). Cadmium-induced changes in the growth and oxidative metabolism of pea plants. $J$ Exp Bot 52: 2115-2126.

11. Hernandez LE, Carpena-Ruiz R \& Garate A (1996). Alterations in the mineral nutrition of pea seedlings exposed to cadmium. $J$ Plant Nutr 19(156): 1581-1598.

12. Rodriguez-Serrano M, Romero-Puertas MC, Zabalza A, Corpas FJ, Gomez M, Rio LA \& Sandalio LM (2006). Cadmium effect on oxidative metabolism of pea (Pisum sativum L.) roots. Imaging of reactive oxygen species and nitric oxide accumulation. Plant Cell Environ 29: 1532-1544.

13. Husiman \& Van DP (1994). Cadmium speciation in soil solutions. J Environ Qual 19: 366-372.

14. Mahvi RD \& Beckett PHT (2005). Critical tissue concentrations of potentially toxic elements. Plant Soil 85: 107-129.

15. Khouri JC \& Randhawa NS (1994). Micronutrients. FAO Fertilizer and Plant Nutrition Bull No. 7. Rome: pp. 82-88.

16. Toze $S$ (2006). Reuse of effluent waterbenefits and risks. Agric Water Manag 80: 147-159.

17. Kaushik \& Garg (2004). Effect of zinc fertilization on cadmium toxicity in durum and bread wheat grown in zinc-deficient soil. Environ Pollut 131: 453-459.

18. Zille H, Shahida N, Abdur R, Asad U \& Inayat K (2012). Effect of domestic and industrial waste water on germination and seedling growth of some plants. Curr Opin Agric 1(1): 27-30. 